\title{
TOTALITARIANISM AND THE ROLE OF RELIGION IN THE INCA STATE
}

\section{Tarmo Kulmar}

The study of the totalitarian state is particularly topical today, since the most recent history of the 20th century offers classical and cautioning corresponding examples in sufficient numbers. As the totalitarian state represents the antithesis of the law-governed state, it is necessary to explore its historical precedents, genesis, characteristics and power mechanisms.

According to an authoritative and widespread opinion (held by Hannah Arendt (Arendt 1966), Carl J. Friedrich and Zbiegniew K. Brzezinski (Friedrich, Brzezinski 1956), Juan J. Linz (Linz 1975), etc.) the totalitarian state is a 20th-century phenomenon. However, the study of the history of some ancient and medieval non-Christian states would bring to light material allowing the conclusion that some so-called oriental despotisms, or societies oriented towards the "Asian way of production", as K. Marx has put it (Marx 1981), have in certain historical circumstances lapsed into a totalitarian form of government. Probably, the first society known to be totalitarian was the Qin Empire, founded on the legistic doctrine (faxia) of Shang Yang, in Ancient China (230-208 BC) ${ }^{1}$ (see e.g. Perelomov 1962 and 1981).

Below I intend to demonstrate that Tahuantinsuyu (Land of the Four Quarters), the state of the ancient Peruvian Incas and the most powerful empire of pre-Columbian America, the societal structure and religion of which has aroused the interest of historians and religious historians from several aspects, numbered among early totalitarian states. ${ }^{2}$ Significantly, the same opinion has also been expressed, even if very cautiously, by Peruvian scientists Maria Rostworowski de Diez Canseco (Rostworowski 1988: 181-233) and Waldemar Espinoza Soriano (Espinoza 1990: 483-499). Let us examine, then, what the society was really like and what role religion had in its functioning.

The above-mentioned investigators of 20th-century totalitarianism, Friedrich and Brzezinski, define the syndrome of totalitarianism by 
six symptoms: an official ideology, a single mass party headed by the elite, a system of terroristic police control, a complete monopoly of control of the means of mass communication, the party's monopolistic control of the means of armed combat and a central control and direction of the entire economy (Friedrich 1954: 47-60; Friedrich, Brzezinski 1956: 5-30). Naturally, there are other definitions around.

While accepting these schemes, which primarily befit the study of 20th-century totalitarianism, I find it better to apply a somewhat different scheme in researching totalitarian states of the more distant past. The first reason is that they belong to a level of historical development at which one cannot yet speak neither of a system of political parties nor of mass communication. Second, in my opinion the scheme given above does not provide exhaustive representation of all walks of life.

Therefore, I will first try to establish as many walks of societal life as possible that, when expressed in a certain manner, would serve as characteristics of a social order that is totalitarian, and then will divide them into seven categories. The first category centres on the historical process and considers the preconditions for and conditions of a state's genesis, existence and termination in general. The next five categories of characteristics concern domestic policy and the last category foreign policy. The extreme forms of these characteristics may prove to be symptoms of a totalitarian state. Some of the characteristics are of a more general nature and may overlap in different categories. Each category ends with a brief description of such manifestation of its characteristics that is symptomatic of a totalitarian society.

\section{HISTORICAL BACKGROUND}

The particular historical mechanism of a state's genesis.

The temporal duration of a state.

The particular historical mechanism of a state's destruction.

A totalitarian state normally emerges in a domestic or foreign policy crisis in a subjective manner taking advantage of the objective risk 
factors, lasts for a relatively short period and perishes either because of an inner crisis or under foreign pressure.

\section{ADMINISTRATION}

A state's level of delegation of authority and dependence on the people.

Administrative and political centralisation.

Bureaucratisation of the state machinery.

Control of the spread and use of information.

A totalitarian state is characterised by a power elite that is distanced from the people, a strictly centralised government, extreme bureaucratisation of the officialdom and near-total control of the spread and use of information.

\section{ECONOMY}

Form of ownership.

The level of autarky in economy.

The level of centralised planning and specialisation in production.

The attitude towards the obligation to work.

The level of regulation in market relations.

The level of coercion in the realisation of major national projects. The economy of a totalitarian state is characterised by the dominance of public ownership over private ownership or by no private ownership, orientation toward a maximally autarkic economy, strict and rigid planning and control of production and consumption, universal obligation to work, artificially imposed market relations and the exercise of governmental coercion in the realisation of major national projects. 


\section{SOCIAL LIFE}

The level of regulation of the way of life.

The relationship between freedom of movement and serfdom.

Subjective public rights: the level of personal liberty.

The existence of segregation.

The demographic policy.

A totalitarian state is characterised by orientation towards regulation of the way of life using governmental planning and control mechanisms, restriction of freedom of movement and other personal liberties, segregation of certain social classes, assimilation of certain social groups, systematic repression up to complete annihilation of minorities and governmental control over demographic processes.

\section{LEGAL ORDER}

Legislation.

The proportion of private to joint responsibility.

Subjective public rights: permissibility of dissidence.

Governmental mechanism of law enforcement.

The legal order of a totalitarian state is characterised by legislation based on the principle "that which is not permitted is prohibited", severe punishments, the dominance of joint responsibility over private responsibility, persecution of dissenters and a terroristic repression machinery.

\section{IDEOLOGY}

The existence of an official national philosophical or religious doctrine.

National cults (including the personality cult of the ruler and mass ceremonies).

Justification of the ethnic policy.

Educational policy. 
Censorship of information.

Propaganda machinery.

In a totalitarian state, a particular philosophy or religion has been turned into the official state religion by the special propaganda machinery. This is accompanied by a mythologised personality cult and well-orchestrated mass ceremonies, indoctrinated ethnocentrism and purposively oriented educational and cultural policy together with censorship of information and of the concept of history to achieve unification of thinking.

\section{FOREIGN POLICY}

Attitude towards the neighbouring countries.

Existence of an offensive strategy.

The means of realisation of the foreign policy.

The foreign policy of a totalitarian state is characterised by a drive for political hegemony over the neighbouring territories, perpetual preparation for aggression and constant readiness for realising the aggression and systematic implementation of the state policies using power politics and military means.

Having thus created a scheme for studying the subject under discussion, I will now reformulate the said seven brief descriptions indicative of totalitarianism into seven propositions concerning the state of the ancient Peruvian Incas and then will try to prove these propositions. The respective vivid examples are taken either directly from the writings of the 16-17th century Spanish chroniclers or from studies based on these chronicles.

\section{HISTORICAL BACKGROUND OF THE INCA STATE}

The Inca state emerged in a domestic or foreign policy crisis in a subjective manner taking advantage of the objective risk factors, lasted for a relatively short time and perished due to the combined effect of an inner crisis and the pressure of a foreign power.

By the early 15th century, a confederacy of six Quechua city-states, Cuzco, Pisaq, Paucartampu, Urupampa, Ollataytampu and Machu 
Picchu, had developed. The city-states were formally tributaries to the state of Colla of the Aymara tribes founded upon the ruins of Tiahuanaco. An invasion by a powerful tribal alliance of the Chancas effected the emergence of Cuzco as the hegemon - thus, the crisis was conditioned by foreign policy developments. In the face of the foreign threat, the ruler of the Incas, Pachacutek Yupanqui king of Cuzco, joined under his leadership the military forces of all the Quechua city-states. After smashing the Chancas, Pachacutek, taking advantage of his military supremacy, turned against the rest of the Peruvian states, including Colla, in 1438, conquered them one after another, and established an empire in the mid-15th century. The form of government was developed by the next emperor, Tupac Yupanqui. The approximately 50 years of perpetual wars of conquest and the inflexible social policy ended in a contest for the throne and a civil war in 1531. The weakened state proved easy prey for the Spanish conquistadors, who arrived a year later (Busto 1981: 47-78; Espinoza 1990: 77-114; Mason 1978: 120-139; Prem 1989: $61-69)$.

\section{ADMINISTRATION OF THE INCA STATE}

In the sphere of government, the Inca state was characterised by an inheritable and services-based power elite that was distanced from the common people, administrative centralisation, bureaucratised officialdom and the pursuit to gain information about all the walks of life.

The Incan power pyramid was topped by the emperor wielding unlimited authority - the One and True Inca. Incas were the name for the Quechua elite, which constituted a closed class. Only members of the Inca families were eligible to hold the leading civil and military positions, and only they could enjoy the various privileges. Even though the subsequent times saw the emergence of several intermediate groups - the so-called Incas by privilege (the common Quechuas living in the Cuzco valley) and the so-called mixed-blood Incas (conceived with women of other tribes) - they never attained to the rights of the Incas.

The Inca state was divided into four large provinces. The smallest registered entity was the communal family, followed by units of 
ten, fifty, one hundred, five hundred, one thousand, five thousand, ten thousand, fifty thousand and one hundred thousand. The units of up to fifty were governed by local village elders, the greater units by hereditary nobles of subjugated peoples - the collaborators. The four provinces were ruled by governors, who were of Incan descent. The central authority in Cuzco, however, delegated higher officials of Incan descent to control and direct the local administration in the sc. localities.

An advanced network of roads, post stations and a courier service enabled the state to maintain effective communication with all its parts. The statistics service, which based its operations on the quipu, registered all the production in the localities as well as the events occurring in all the spheres of activity, including domesticity and procreation, and sent the data gathered to the highest department of control and planning, which then drew up instructions for the localities (Vega 1988: Libro I, cap. XXVI, Libro II, cap. XI-XII, Libro V, cap. XIII-XVI, Libro VI, cap. VII-IX, Libro VII, cap. I; Cieza de León 1987: cap. LIX, LX, XCII, XCIII, CV; Guaman Poma de Ayala 1980: 88-97, 312-338; Espinoza 1990: 297-396; Oberem 1990: 467491; Prem 1989: 69-76).

\section{ECONOMY OF THE INCA STATE}

In the sphere of economy the Inca state was characterised by limited private ownership, autarkic production, planned specialisation of production, centrally planned barter trade and construction of grand facilities by masses of people under state coercion.

The Inca state had only one form of private ownership: all the land belonged to the ruler. The community only had the right and obligation to work it. Tracts of land were periodically reallocated in accordance with the number of people living in a community.

The communities specialised in land tillage, cattle breeding or handicraft; this specialisation was imposed according to plan under the guidance and supervision of the state. As community members were guaranteed the minimum of subsistence by the central authority and the rest of their production was expropriated, money and mar- 
ket trading were completely non-existent, not to mention foreign trade. The state met its needs by autarkic production.

New farming lands were broken in conquered territories and people were forcibly resettled there from different regions of the state by whole communities. Labour and transportation conscription was employed to build a network of roads criss-crossing the entire state, irrigation systems, terraced fields and military and public facilities (Vega 1988: Libro V, cap. I-X, XIII-XVI; Cieza de León 1987: cap. LXVI, LXXIV-LXXX, CX-CXIV; Guaman Poma de Ayala 1980: 306312; Oberem 1990: 467-491; Rostworowski 1988: 261-282; Mason 1978: 140-150).

\section{SOCIAL LIFE OF THE INCA STATE}

In the sphere of social life the Inca state was characterised by a regulated way of life, serfdom, social homogenisation, all-pervading control and planning, a total lack of personal freedoms and ethnic assimilation of the subjugated peoples.

In the Inca state, the life of a community member was divided into ten age groups. Each group entailed its obligations. The obligation to work was imposed already since childhood. A $25-30$-year-old community member practiced the profession assigned to him, for which he had started to receive compulsory training already as a child. Marriage and reproduction of the population was mandatory.

A community member was attached to the territory of its village. He was not allowed to leave, even for a short time, without the permission of the head of its unit or the state official, who was an Inca. The agents of the Statistics Department monitored all the events in the life of each member of both the community and the tribal aristocracy. In addition, the members were to watch one another and inform the state official of any act of lawbreaking, however small.

For the purpose of unification of the languages and customs of the different regions the subjugated tribes were resettled to other regions of the state by whole communities, and communities of Incas by privilege were settled to the territories of subjugated tribes. The land tillers' and cattle breeders' communities deported to newly 
broken lands lived in militarised settlements. The localities were under the charge of state officials and garrison officers of Incan descent (Vega 1988: Libro IV, cap. 12-14, Libro V, cap. I-X, XIIIXVI; Cieza de León 1987: cap. LXII, CX-CXIV; Guaman Poma de Ayala 1980: 172-209; Espinoza 1990: 115-180, 275-296; Cunow 1937: 97-126; Mason 1978: 180-205).

\section{LEGAL ORDER OF THE INCA STATE}

In the sphere of legal order, the Inca state was characterised by draconian laws entailing cruel penalties up to mass repressions, the principle of joint responsibility and eradication of any dissenting opinion by means of a special state terror machinery.

The Inca state was governed by the principle "do not laze, do not lie, do not steal". Smaller offences committed for the first time were punished with a warning while corporal punishment was the penalty for the second time and capital punishment for the third time. Imprisonment was hardly known. Serious offences were inevitably punished with the death penalty. The ultimate crime, of course, was blasphemy against the sun god Inti, followed by crimes against the state and the emperor. The latter included a very wide variety of crimes, including serious transgressions against generally accepted moral standards. Non-performance of the obligation to watch one another's activities and inform the authorities of any act of wrongdoing was also considered a crime endangering the regime. Joint responsibility was applied to especially severe offences against religion and the state: the punishment was meted out not only to the offender but also to his family, in extreme cases even to the entire community. At the same time, the elite was more equal than the rest of the population: for the same offences, the penalties prescribed for pureblood Incas as representatives of the upper class were much milder.

A few examples. Any social protests and manifestations of dissidence were qualified as sacrilege, for which both the transgressor and his close family were sentenced to death in a cellar crawling with venomous snakes. Illicit sexual relations with a sun-maiden or one of the emperor's concubines were penalised by burning the parties involved and hanging his family. If in violation of the ban a 
community member married a virgin appointed to become an aristocrat's concubine, both were stoned to death.

In the localities the law and order was monitored by the collaborationist tribal elite subjected to the state officials, who were of Incan descent, while the law enforcement function was fulfilled by the local garrison. Smaller sentences were passed by heads of units while capital sentences were handed out by the official of Incan descent on application from the village chief and executed by the community members. Appellation was an unknown phenomenon. For the first time in 1531, during the civil war, large-scale repressions were performed: the mixed-blood pretender to the throne, Atahuallpa, established a number of concentration camps in which mass executions of pureblood Incas took place (Vega 1988: Libro II, cap. XIII, Libro V, cap. XI, Libro IX, cap. XXXV-XXXIX; Guaman Poma de Ayala 1980: 276-288; Cunow 1937: 159-174; Busto 1981: 199-202; Mason 1978: 203-205).

\section{IDEOLOGY OF THE INCA STATE}

In the sphere of ideology the Inca state was characterised by the use of state religion to justify and legalise the regime, the cult of the sovereign ruler, orchestration of purposive cultic ceremonies with mass attendance, ethnocentrism as a foreign policy doctrine, censorship of information and history, selective and purposive use of school education and the existence of special propaganda machinery.

Figuratively speaking, two religions can be distinguished in the Inca state. Locally, there were tribal cults and all sorts of subcults, which were built on nature worship. They may be treated in their "natural" context of religious history.

The official state religion, however, was the cult of the sun god Inti of the Quechuas, officiated by the priests. According to that religion, the emperor of the Incas - the One and True Inca - was the living god on earth, the terrestrial incarnation of the Sun God. The state was deemed as created by the Sun God, and the emperor, as His vicegerent, was appointed together with his fellow Incas - the sons of the Sun - to sustain, expand and rule it. The justifications 
for the existence of the Inca state were preventing chaos, maintaining order on earth and making all people, particularly its subjects, happy.

The holding twelve times a year of mass religious feasts, of which the most important was Inti Raymi, the Sun Feast of the winter solstice, was aimed, apart from serving the chief gods of the pantheon, at unification of thinking and generating national euphoria for the purpose of strengthening the regime and the unity of the state. Such days were holidays full of solemn ceremonies, merry celebrations and free eating and drinking catered for by the state.

The sun god religion also provided justification for wars of conquest: according to the teaching of the Incas, the Father Sun had commanded to spread civilisation to all nations, which presupposed perpetual military aggressions, since the barbarians were unwilling to voluntarily embrace its benefits. The Inca state was considered the centre of the world and the peak of civilisation, which is manifested in its official name - the Land of the Four Quarters. The centre of the state, in turn, was the capital Cuzco, the English for which is the Hub of the World. The civilisation-spreading doctrine was developed during Pachacutek Yupanqui's wars of conquest in order to secure the submission of the subjugated peoples. The doctrine was refined to perfection by the subsequent emperors Tupac Yupanqui and Huayna Capak.

Thus, at the core of the doctrine was the state's being ordained by the Sun God. That concept was inculcated into the masses by means of religious feasts, draconian laws and a tendentious educational system.

As far as is known, the Inca state had no writing system in the modern sense of the word. According to the chronicler Montesinos, it had had a writing system once but that was destroyed for some reason and barred from use on pain of death. The primary function of the quipu, or a record-keeping device based on a complicated system of knots, was to register and reproduce statistical data.

The historical tradition was completely harnessed to the service of religious and political purposes: specifically trained "memorisers" retained in their memory the state's history in verse, which had 
previously been censored by the authorities. The account of the deeds of a deceased emperor were approved before public pronouncement by his successor to the throne. Such a history was presented to the people during the feasts, and children were to memorise it at school. The living history tradition was destroyed in the civil war and in the conquests of the Spaniards, surviving only on the pages of Spanish chronicles.

The Incas founded two types of schools. They had the so-called specialised vocational schools for the common people, which apart from working techniques taught basic religious and political truths. The schools intended for the power elite provided instruction in the art of warfare, administration, the quipu, religion and history; naturally, there was specialisation in them as well.

The ideologised policy of religion was implemented by the priesthood, which was no closed class but rather a propaganda department, to which school graduates with certain personality traits were appointed. The position of the high priest of the state cult was assigned to a high-ranking official, usually a close male relative of the emperor (Vega 1988: Libro I, cap. IX-XI, Libro II, cap. I-IX, Libro III, cap. XX-XXV, Libro IV, cap. I-V, Libro VI, cap. XX-XXIV; Cieza de León 1987: cap. XIX, LXI, LXIV, LXXII, CI; Ayala 1980: 210-245, 272-275; Cobo 1893: Tomo IV; Varcárcel 1964: Tomo 3; Busto 1981: 180-193, 283-316; Kelm 1990: 519-533; Espinoza 1990: 483-499; Cunow 1937: 175-208).

\section{FOREIGN POLICY OF THE INCA STATE}

The aggressive hegemonist and expansionist foreign policy of the Inca Empire served as a means of implementing the official state religion as a politicised religious doctrine.

Proceeding from the above, it is clear that wars of conquest were a natural part of the politics in the Inca state, being instituted by a central religious concept - the mission given to the Incas by the sun god of spreading civilisation forcibly to all the nations. The history of the Inca state is therefore a history of perpetual wars of conquest. 
In its final period, the Land of the Four Quarters extended from modern-day Ecuador to Central Chile, thus for more than 3,000 kilometres from north to south. Its 15-million-strong population was able to put out a standing army of up to 400,000 well-armed men. Military training was given to all the healthy male subjects; in the case of the Incas themselves, the training ended with a kind of initiation rite - the trial of bravery. Under the conscription scheme, all young men aged 18-25 years served in the regular forces. The top brass was composed exclusively of Incas. Members of the militarised communities in frontier regions simultaneously served as border guards, supported by the local law-enforcement garrisons (Vega 1988: Libro III, cap. IV, Libro V, cap. XII; Ayala 1980: 122-151; Busto 1981: 209-234; Prem 1989: 71; Oberem 1990: 467-491).

Even this rather cursory analysis makes it clear that the abovementioned seven propositions concerning the Inca state are warranted to a fairly great extent. Based on the material considered, two conclusions may be drawn:

1. All the seven categories of characteristics suggest that the state of Tahuantinsuyu of the Incas corresponds in a rather large measure to a totalitarian state. Consequently, this analysis has again corroborated the assumption that the so-called early totalitarian states may have existed already in the distant past.

2. The issue of ideology was especially emphasised above in the context of Tahuantinsuyu, since ideology plays a central role in the theory of the 20th-century totalitarian state. Obviously, the same holds good for totalitarian states of the distant past. Accordingly, it is particularly in societies not yet having philosophical doctrines that the official religion was harnessed to serve the state in the functions of ideology. This is true at least of Tahuantinsuyu.

However, it must also be taken into account that religion always has a series of humanistic and man-centred functions to fulfil in each society. Neither should we forget in this particular case that the sun worship of the Incas stands out among the pre-Columbian Mesoamerican religions by its relative mildness and the exceptionality of human sacrifice. Hence, it would be incorrect to view as negative the Inca religion itself; rather, it is the elite of 
Inca society that can be blamed for wielding it in such a manner to consolidate their power.

\section{Comments}

The current article has been supported by the Estonian Science Foundation grants 4893 and 5374.

${ }^{1}$ This has never been maintained expressly in scientific literature but has been indirectly. As well, the data presented by researchers lends itself to such interpretation. Therefore the issue definitely requires further study.

${ }^{2}$ Naturally, one must not overlook L. Baudin's (see Baudin 1956) attempt to characterise the Inca state as the world's first Socialist society. This treatment perforce attributes totalitarian traits to the Incas.

\section{References}

Arendt, Hannah 1966. The Origins of Totalitarianism. New York: Harcourt, Brace \& World.

Baudin, Louis 1956. Der sozialistische Staat der Inka. Rowohlts deutsche Enzyklopädie 16: Ethnologie. Hamburg: Rowohlt.

Busto Duthurburu, José Antonio del 1981. Perú incaico. Lima: Librería Studium Ed.

Cieza de León, Pedro 1987. La crónica del Perú, vol. 3. Colección Clásicos peruanos. Lima: Pontificia Universidad Católica del Perú.

Cobo, Bernabé 1893. Historia del Nuevo Mundo IV. Sociedad de Bibliofilos Andaluces: Serie 1: 18. Sevilla: Imp. de E. Rasco.

Cunow, Heinrich 1937. Geschichte und Kultur des Inkareiches: Ein Beitrag zur Kulturgeschichte Altamerikas. Amsterdam: Elsevier.

Espinoza Soriano, Waldemar 1990. Los Incas: Economía, sociedad y Estado en la era del Tahuantinsuyo. Lima: Amaru Editores.

Friedrich, Carl Joachim \& Brzezinski, Zbiegniew K. 1956. Totalitarian Dictatorship and Autocracy. New York: Praeger.

Friedrich, Carl Joachim 1954. The Unique Character of Totalitarian Society. Friedrich, Carl Joachim (ed.) Totalitarianism: Proceedings of a conference held at the American Academy of Arts and Sciences, March 1953. Cambridge: Harvard University Press, pp. 47-60, discussion pp. 74-84.

Garcilaso de la Vega, Inca 1988. Comentarios reales de los Incas, 1-3. Lima: Editorial Mercurio S.A. 
Guaman Poma de Ayala, Felipe 1980. El Primer Nueva Corónica y Buen Gobierno. Colección América nuestra 31: América Antigua. Ciudad de México: Siglo Veintiuno.

Kelm, Antje 1990. Grundzüge der Religionen des zentralen Andenraumes. Köhler, Ulrich (ed.). Altamerikanistik: Eine Einführung in die Hochkulturen Mittel- und Südamerikas. Berlin: Dietrich Reimer Verlag, pp. 519-533.

Linz, Juan J. 1975. Totalitarian and Authoritarian Regimes. Greenstein, Fred I. \& Polsby, Nelson W. (eds.) Macropolitical theory. Handbook of Political Science = Addison-Wesley series in political science, Vol. 3. Reading (Mass.): Addison-Wesley, pp. 175-196, 264-274.

Marx, Karl 1981. Formen, die der kapitalistischen Produktion vorhergehen. Ökonomische Manuskripte 1857/58. Marx, Karl \& Engels, Friedrich. Gesamtausgabe (MEGA), Abt. 2, Bd. 1, Teil 2. Berlin: Dietz, pp. 378-415.

Mason, John Alden 1978. The Ancient Civilizations of Peru. New York: Penguin Books.

Oberem, Udo 1990. Das Inkareich unter politischem, sozialem und wirtschaftlichem Aspekt. Köhler, Ulrich (ed.). Altamerikanistik. Eine Einführung in die Hochkulturen Mittel- und Südamerikas. Berlin: Dietrich Reimer Verlag.

Perelomov, Leonard 1962. Imperiia Tsin': Pervoe tsentralizovannoe gosudarstvo $v$ Kitae (221-202 gg. do n.e.) [The Tsin Empire: The first centralised state in China (221-202 BC)]. Moskva: Izdatel'stvo vostochnoi literatury.

Perelomov, Leonard 1981. Konfutsianstvo i legizm v politicheskoi istorii Kitaia [Confuzianism and Legality in Chinese Political History]. Moscow: Nauka.

Prem, Hanns 1989. Geschichte Altamerikas. Oldenbourg Grundriss der Geschichte, 23. München: R. Oldenbourg Verlag.

Rostworowski de Díez Canseco, María 1988. História del Tahuantinsuyu. Lima: Instituto de Estudios Peruanos de Ministerio de la Presidencia, Consejo Nacional de Ciencia y Tecnología.

Varcárcel, Luis Eduardo 1964. Historia del Perú antiguo: A través de la fuente escrita, 3: Religión, magía, mito, juego. Lima: Librería Editorial Juan Mejía Baca.

Vega, Inca Garcilaso de la (1988). Comentarios Reales de los Incas, IIII. Lima: Editorial Mercurio S.A. 